\title{
Nutritional Characterization of Moringa (Moringa oleifera Lam.) Leaves for Forage Use
}

\section{Rubén Rosales Ramírez ${ }^{1}$, J Jesús Vargas Radillo² ${ }^{2}$ Cecilia Neri Luna ${ }^{3}$, Lucía Barrientos Ramírez ${ }^{1 *}$ and Manuel Mateo Hernández Villegas ${ }^{4}$}

${ }^{1}$ Department of Animal Production, CUCBA, University of Guadalajara, Jalisco, Mexico

${ }^{2}$ Department of Wood, Pulp and Paper, CUCEI, University of Guadalajara, Jalisco, Mexico

${ }^{3}$ Department of Ecology, CUCBA, University of Guadalajara, Jalisco, Mexico

${ }^{4}$ Popular University of Chontalpa, Tabasco, Mexico

*Corresponding Author: Lucía Barrientos Ramírez, Department of Animal

Production, CUCBA, University of Guadalajara, Jalisco, Mexico.
Received: October 25, 2021

Published: November 29, 2021

(C) All rights are reserved by Lucía Barrientos

Ramírez., et al.

\section{Abstract}

The aim of this work was to evaluate the nutritional content, amino acids, phytochemical compounds (phenols, tannins and flavonoids) in ethanol extract, minerals and fatty acids, in Moringa oleifera leaves under the edaphoclimatic conditions typical of the central-northeast region of Jalisco, Mexico. In animal feed, moringa consumed fresh, directly, as part of a diet, or in silage, has favorable properties in the nutrition and health of cattle, chickens, fish, goats, pigs and lambs, and has become in an alternative to the traditional grain-based use. Due to its favorable properties, moringa is one of the most used vegetables for forage use.

Keywords: Chemical Composition; Amino Acids; Fatty Acids; Tannins; Linoleic Acid

\section{Introduction}

Livestock and poultry production is an activity of great importance in the food industry. The current trend is the inclusion in the diet of plants and their extracts as supplements that function as substitutes for antibiotics [1], in addition to the fact that there is a limited supply of grass-based forages [2]. Among the most promising plant resources for this purpose is Moringa oleifera Lam., A tree native to the southern Himalayas and northwestern India. It belongs to the Moringacea family. It grows in tropical areas below 500 masl, although it can adapt to edapho-climatic conditions in places above 1,500 masl. In Mexico it is distributed throughout the Pacific coast [3]. This species is very versatile since all its organs, pods, flowers, bark, roots and leaves can be used, since they contain medicinal properties. This plant has functioned as a nutritional source in diets for the population in different countries of the world, and it has also had forage and fertilizer use $[4,5]$. It has a high content of protein, carotenoids, vitamins, minerals, chlorogenic acid, gallic acid, kaempferol, glycosides and quercetin in its leaves $[6,7]$. Consumption of moringa has been shown to increase meat yield in animals, antiparasitic and curative effect [8]. It has been used as a forage resource with yields of up to 21 tons of dry matter/ha [9]; In particular, the moringa leaf has been used as a dietary supplement and activator of the immune system [10], improving productivity and increasing the digestibility of nutrients [11], being supplied in various ways, such as fresh feed, supplement for pasture or silage. Since the nutritional composition of plants is dependent on the climate and place of growth or cultivation [12], the objective of this work is to present the nutritional potential of M. oleifera cultivated under the edaphoclimatic conditions of the area of sampling (Central West of Mexico), through the nutritional evaluation, amino acids, mineral and phytochemical composition of the leaves, in the search for alternatives or supplements of grains and cereals commonly used in animal production. 


\section{Materials and Methods}

The research was carried out in the Nutrition Laboratory of the University Center for Biological and Agricultural Sciences (CUCBA) of the University of Guadalajara, Zapopan, Jalisco, Mexico.

Plant sampling

Moringa leaves were collected in July 2017, from adult trees in a crop located in the municipality of Cuquío $\left(20^{\circ} 55^{\prime} 6^{\prime \prime} \mathrm{N}, 103^{\circ} 01^{\prime} 3^{\prime \prime}\right.$ $\mathrm{W})$, Jalisco, Mexico, in the center-northeast of the State at a height of 1,810 masl. The climate is semi-dry, dry and semi-warm winter and spring with mild winter, average annual temperature $17.9^{\circ} \mathrm{C}$, average annual rainfall 839.5 millimeters, rains in June, July and August.

\section{Material Preparation}

The leaves were dried at room temperature $\left(25^{\circ} \mathrm{C}\right)$ for 7 days. Subsequently, the material was pulverized in a Restsch-Gnbh brand blade mill, and it was sieved on a 70-mesh screen (opening 0.21 $\mathrm{mm}$ ), using the material that passed through this mesh.

\section{Proximal chemical analysis}

This analysis was made according to Valdez-Solana., et al. (2015) [13]. The ground leaves were treated with cold hexane at $4^{\circ} \mathrm{C}$ to remove fats, since they interfere with the analyzes. Crude protein (CP) (\% N x 6.25), crude fiber (CF), fat content, moisture, ash and carbohydrates (or nitrogen-free extract, ELN), calculated by difference, were evaluated on the dislipidized material. Neutral Detergent Fiber (NDF) and Acid Detergent Fiber (FDA) were determined, applying the Van-Soest technique (1991) [14].

\section{Amino acids}

The grinded leaf sample was hydrolyzed with $\mathrm{HCl}\left(6 \mathrm{~N}, 105^{\circ} \mathrm{C}\right.$, $24 \mathrm{~h}$ ), neutralized with $6 \mathrm{~N} \mathrm{NaOH}$ and filtered. The amino acids were evaluated using an HPLC (Varian), reversed phase (C18 column) with fluorescence detector, with derivatization in precolumn with Orthophthaldehydothiol (OPT) [15].

\section{Mineral composition}

Macrominerals and microminerals were determined by atomic absorption spectrophotometry (Perkin-Elmer spectrophotometer) [16]. all analyzes were performed by 3 repetitions $(n=3)$.
Fatty acids

The analysis was done according to standard procedures [17], using a gas chromatograph (Hewlett-Packard, HP-5890, series II), equipped with flame ionization detector.

\section{Extraction process}

The ground and dry material (100 g. Dry weight) was extracted with $500 \mathrm{~mL}$ of ethanol for 5 days at $25^{\circ} \mathrm{C}$ and $150 \mathrm{rpm}$ in an incubator (LabTech model LSI-3016R). The material was filtered with Whatman No.4 paper and the filtrate was concentrated in a Buchi rotary evaporator under reduced pressure and $40{ }^{\circ} \mathrm{C}$, keeping it in the freezer until the tests were carried out.

\section{Total phenols}

The Folin Ciocalteau assay was applied. A standard curve for Gallic Acid (0-100 $\mu \mathrm{g} / \mathrm{mL})$ was prepared in $20 \mu \mathrm{g} / \mathrm{mL}$ intervals. Absorbance $(\lambda=760 \mathrm{~nm})$ was measured [18].

\section{Flavonoids}

The $\mathrm{AlCl}_{3}$ Technique was applied [19]. $5 \mathrm{mg}$ of extract were weighed and dissolved in $1 \mathrm{~mL}$ of distilled water. It was diluted 1:10 in distilled water. $1250 \mu L$ of distilled water were added to each of the standards and test samples, and after adding $75 \mu \mathrm{L}$ of $5 \% \mathrm{NaNO}_{2}$. They were allowed to stand for 6 minutes. $150 \mu \mathrm{L}$ of $10 \% \mathrm{AlCl}_{3}$ were added and the mixture was left to stand for 5 minutes. Later, $500 \mu \mathrm{L}$ of $1 \mathrm{M} \mathrm{NaOH}$ were added and finally the volume of each reference and sample was completed at $2.5 \mathrm{~mL}$ with distilled water. The sample was allowed to stand 30 minutes and the absorbance at $510 \mathrm{~nm}$ was measured. A standard curve was prepared with Catechin.

\section{Condensed tannins}

The vanillin method was applied [20], with some changes. $20 \mathrm{~g}$ of ground dry leaves were treated with $200 \mathrm{ml}$ of absolute methanol and centrifugation was applied (9,000 rpm, $20 \mathrm{~min})$. Subsequently, $10 \mathrm{~g}$ of activated carbon was added, and it was centrifuged again (5000 rpm, $10 \mathrm{~min}$ ), recovering the supernatant. For the evaluation of the condensed tannins, $5 \mathrm{ml}$ of the crude extract were treated with $25 \mathrm{ml}$ of freshly prepared vanillin reagent $(10 \%$ vanillin in methanol and $80 \%$ hydrochloric acid in methanol, 1: 1). It was left to rest in a water bath for $20 \mathrm{~min}$ at $30^{\circ} \mathrm{C}$. Subsequently, the absorbance of the sample was read at $500 \mathrm{~nm}$ in a UV spec- 
trophotometer (Velab). A catechin standard curve was prepared. It was reported as gEC/100 $\mathrm{g} \mathrm{dw}$.

\section{Statistical analyzes}

The tests were done in triplicate. Basic statistics were applied to calculate the arithmetic mean and standard error.

\section{Results and Discussion}

Chemical composition, secondary metabolites, minerals

Results are shown in table 1 . The values shown are those obtained in proximal chemical analysis, phytochemical analysis and mineral profile.

\begin{tabular}{|l|c|c|c|}
\hline Parameter & M. oleifera, \% & $\begin{array}{c}\text { Soybean } \\
\text { meal, \% } \\
{[\mathbf{2 1}]}\end{array}$ & $\begin{array}{c}\text { Maize, \% } \\
{[\mathbf{2 2}]}\end{array}$ \\
\hline Crude protein & $25.50 \pm 0.81$ & 49.22 & 7.10 \\
\hline Crude Fat (lipids) & $7.4 \pm 0.62$ & 1.27 & 4.18 \\
\hline Carbohydrates (NFE) & $58.20 \pm 2.63$ & --- & 75.48 \\
\hline Ash & $5.40 \pm 0.61$ & --- & 1.79 \\
\hline $\begin{array}{l}\text { Neutral Detergent } \\
\text { Fiber (NDF) }\end{array}$ & $10.35 \pm 0.61$ & 14.88 & 6.69 \\
\hline Acid Detergent Fiber & $7.36 \pm 0.57$ & 6.62 & --- \\
\hline ADF) & $3.29 \pm 0.54$ & --- & 0.174 \\
\hline Phenols (gGAE/100g) & $0.367 \pm 0.41$ & --- & 0.048 \\
\hline CT (gEC/100g) & $3.06 \pm 0.55$ & --- & 0.005 \\
\hline Flavonoids \\
(gCE/100g) & $4.45 \pm 0.297$ & --- & --- \\
\hline Nitrogen & $0.24 \pm 0.070$ & 0.72 & 0.284 \\
\hline Phosphorus & $6.16 \pm 0.087$ & --- & 0.276 \\
\hline Potassium & $0.25 \pm 0.0454$ & --- & 0.037 \\
\hline Sodium & $2.23 \pm 0.075$ & 0.43 & 0.011 \\
\hline Calcium & $0.38 \pm 0.030$ & --- & 0.126 \\
\hline Magnesium & $8 \pm 1.00(\mathrm{ppm})$ & --- & 0.064 \\
\hline Copper & $51.4 \pm 1.36$ & --- & 0.001 \\
\hline Manganese & $99.3 \pm 3.05$ & --- & 0.003 \\
\hline Iron & $(\mathrm{ppm})$ & & \\
\hline
\end{tabular}

Table 1: Chemical composition of moringa leaf, compared with commonly used food species.

DM = Dry Matter $; C T=$ Condensed Tannins; NFE $=$ Nitrogen Free

Elements; gGAE= Grams Gallic Acid Equivalent; gCE = Grams Catechin Equivalent.
The data in table 1 show that moringa has a higher protein content than corn but lower than soybean; higher lipid content than corn, but lower than soybean; higher fiber content than corn and similar to soybean. Likewise, the nutritional content is within the standards of the multiple reports that exist on the moringa leaf, in some of them, the chemical composition of $17-22 \%$ is established in crude protein, $2-6 \%$ crude fat, ash $7-8 \%$, crude fiber $7-21 \%$ $[23,24]$. The chemical composition of moringa has positioned it as a vegetable with nutritional and nutraceutical properties. In addition, essential amino acids and fats are used to obtain foods with higher energy levels [25]. According to the data presented in table 1 coinciding with the numerous bibliographic reports-, the moringa leaf has high protein content (25.50\%), as well as an acceptable content of lipids, minerals, low fiber content, presence of secondary metabolites antioxidants, such as phenols, flavonoids and tannins, as well as vitamins, for which it has been consumed and used for various purposes. Usually, the low fiber content indicates a good palatability of the animal feed [26]. The secondary metabolites would provide antioxidant and antibacterial properties to the supplied diet [6]. Moringa improves nutrition, but also improves the immune system of birds and animals, with antimicrobial effect against E. Coli, and increase of Lactobacillus in the intestine [27].

In relation to the phytochemical analysis, the values in table 1 are similar in the content of tannins and flavonoids and slightly lower in phenols, when compared with other analyzes. Nweze and Nwafor (2014) [23] found 3.83\% flavonoids, 9.19\% tannins in addition to other compounds (alkaloids, saponins, carotenoids and others) in ethanol extract; Another study indicates values of $12 \%$ phenols and 4\% flavonoids [28]; also 4.51\% phenols and $2.56 \%$ tannins [11]. In a study done on moringa grown in Mexico (Celaya, Guanajuato), they report $3.3 \%$ in total phenols and $0.007 \%$ in condensed tannins [29]. M. oleifera, particularly the leaves, contains a high percentage of secondary metabolites, which can be used as additives in diets or as direct consumption to increase the quality of the meat [30]. Phenols and flavonoids prevent the potential peroxidation of lipids, improve meat quality -chemical composition and color stability, and lighter color due to the production of conjugated linoleic acid- and the composition of fatty acids [31,32]. Antioxidants improve the immune system of animals protecting them against infections and diseases [32]. High polyphenol contents have a beneficial effect on the rumen microbial population [33]. The presence of flavonoids in moringa leaves increases the content of high-density lipoprotein (Good cholesterol) in the egg, decreases low-density lipoprotein and cholesterol [34]. Tannins, 
an astringent polyphenolic compound considered antinutritional, common in plants, affect the nutritional value of foods by decreasing palatability and intestinal enzymatic digestion [35], with a decrease in intake. However, ruminants can use lignin or cellulose as an energy source since they degrade it to monosaccharides, not so monogastric animals that cannot degrade it. Tannins have a high antioxidant activity, and the antioxidant potential of moringa leaves is due to the concentration of tannins [36]. Since antinutritional factors, in particular hydrolysable tannins and phenols, should not be eliminated from animal feed in their entirety, since they have antioxidant properties, improve meat quality and reduce methane emission in ruminates [26].

The minerals are at the level of other reports. In one of them [23], they mention $3.03 \% \mathrm{~N}, 0.44 \mathrm{P}, 2.09 \% \mathrm{Ca}, 0.48 \% \mathrm{Mg}, 1.62 \% \mathrm{~K}$, in addition to $0.03 \% \mathrm{Au}$, and $0.85 \mathrm{~S}$. Also $0.30 \% \mathrm{P}, 3.65 \% \mathrm{Ca}, 0.50 \%$ $\mathrm{Mg}, 1.50 \% \mathrm{~K}$ [37]. Reviewing the minerals in table 1, a higher mineral content is seen in moringa leaves compared to soybean and corn, used as a comparison, in $\mathrm{K}, \mathrm{Na}, \mathrm{Ca}, \mathrm{Mg}$, but lower content in phosphorus. Minerals are also important for evaluating nutritional properties. Su and Chen (2020) [26], citing several authors, mention that the minerals related to animal growth and development are Calcium, a necessary element for bones, teeth, eggshell, proper functioning of the nervous system, reduction of capillary permeability and regulation of metabolism and enzymatic activation. Gold $(\mathrm{Au})$, promotes animal growth since it is a key component of various proteins and participant in various biochemical reactions. Zinc, necessary in enzymes, is important in the oxygenation of tissues and the metabolism of proteins, fats, sugars and nucleic acids. Magnesium, with favorable effects on milk production.

\section{Amino acids}

The amino acid profile of the moringa leaf (Figure 1) shows that the highest signal corresponds to threonine (Thr), to a lesser extent Proline (Pro), Glycine (Gly) and Asparagine (Asn).

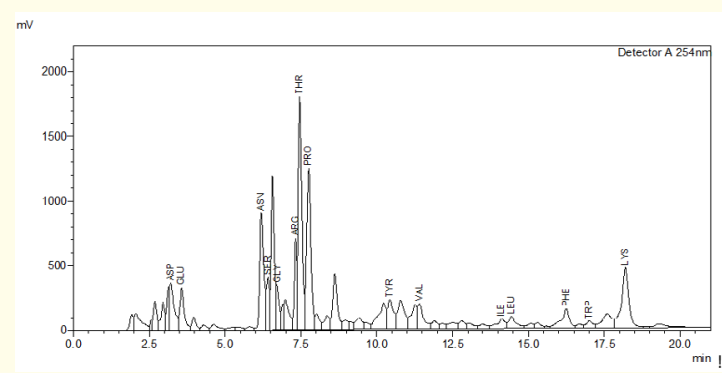

Figure 1: Chromatogram of amino acids present in Moringa oleifera leaf.
The concentrations of the amino acids are presented in table 2 , which includes the references soybean and corn.

\begin{tabular}{|l|c|c|c|}
\hline Amino acid & \multicolumn{3}{|c|}{ Quantity } \\
\hline & M. oleifera & $\begin{array}{c}\text { Soybean meal } \\
{[\mathbf{2 1}]}\end{array}$ & $\begin{array}{c}\text { Maíz } \\
{[\mathbf{3 8 ]}}\end{array}$ \\
\hline Aspartic acid & 2.91 & --- & --- \\
\hline Glutamic acid & 2.55 & --- & 5.70 \\
\hline Asparagine & 4.14 & --- & --- \\
\hline Serine & 0.97 & 2.47 & 1.80 \\
\hline Glycine & 0.63 & 2.28 & 2.50 \\
\hline Methionine* & $\mathrm{ND}$ & 0.66 & 0.90 \\
\hline Cisteine* & $\mathrm{ND}$ & 0.69 & 0.70 \\
\hline Arginine* & 1.62 & 3.64 & 3.82 \\
\hline Threonine* & 7.40 & 2.25 & 2.00 \\
\hline Proline & 3.01 & 2.56 & 1.15 \\
\hline Tyrosine & 2.72 & 1.70 & 2.07 \\
\hline Valine* & 0.86 & 2.47 & 3.00 \\
\hline Isoleucine* & 0.61 & 2.33 & 2.53 \\
\hline Lysine* $^{*}$ & 2.73 & 3.22 & 1.80 \\
\hline Leucine* $^{*}$ & 0.61 & 3.86 & 8.82 \\
\hline Phenylalanine* & 1.16 & 2.49 & 3.50 \\
\hline Tryptophan* & 0.29 & 2.25 & --- \\
\hline
\end{tabular}

Table 2: Amino acids in Moringa oleifera, compared to common foods (Soybean and Maize). (\% of DM).

*Indispensable Amino acids; ND = Not detected.

The amino acid found in the least amount (limiting amino acid) is tryptophan $(0.29 \%)$. In contrast, threonine is the one with the highest percentage (7.4\%). Of the total amino acids presented in this analysis, it contains threonine, valine, leucine, lysine, isoleucine, arginine, tryptophan and phenylalanine as essential. The content of methionine and cysteine/cystine was low (ND). Other studies done on moringa leaves report $0.297 \%$ methionine and $0.01 \%$ cystine [37]. Compared to soybeans and corn, the moringa leaf in this analysis has more threonine. However, it contains a lower content of arginine, valine, isoleucine, leucine and phenylalanine. Similar contents of serine, proline, tyrosine, and lysine are appreciated. In particular lysine, a limiting sulfur amino acid in corn, the content of this amino acid in moringa is approximately 1.5 times higher in relation to the content in corn, but slightly higher in relation to soybeans. However, the amino acid content in moringa is moderate, as shown in the table. Like legumes, and in general inputs of plant ori- 
gin, moringa is low in sulfur amino acids, methionine and cysteine/ cystine. Sulfur amino acids are important in nutrition and growth as they participate in protein synthesis and regulate the percentage of food that is metabolized at the cellular level [39]. Sulfur amino acid deficiency has negative effects on nutrition. Generally, the deficiency in sulfur amino acids is compensated by supplementing the food with fish meal, which is characterized by its high content of methionine and cystine, or gramineous plant (sorghum, corn, wheat) which also improves palatability [40]. However, the content in moringa leaves of the essential amino acids Threonine and Lysine, which are limiting amino acids in cereals such as corn, is noteworthy [41]. Lysine is related to animal growth and threonine to the immune system, the integrity of the intestinal mucosa, and is related to the synthesis of immunoglobulin [42].

Fatty acids

In this analysis, the values of $1.54 \%$ polyunsaturated fat, $0.08 \%$ monounsaturated fat and $0.72 \%$ saturated fat are observed as notable (Table 3).

\begin{tabular}{|l|c|}
\hline Fatty acid & Quantity, \% (DM) \\
\hline Palmitic acid & $0.59 \pm 0.020$ \\
\hline Stearic acid & $0.12 \pm 0.02$ \\
\hline Oleic acid & $0.08 \pm 0.654$ \\
\hline Linolenic acid & $1.29 \pm 0.062$ \\
\hline Saturated fat & $0.72 \pm 0.025$ \\
\hline Monounsaturated fat & $0.08 \pm 0.015$ \\
\hline Polyunsaturated fat & $1.54 \pm 0.020$ \\
\hline
\end{tabular}

Table 3: Fatty acid profile of the dried leaves of $M$. oleifera (\% of DM).

It is also worth mentioning the higher content of linolenic acid (1.29\%) and palmitic acid (0.59\%), with respect to stearic acid $(0.12 \%)$ and oleic acid $(0.08 \%)$. These values are within the standards reported in similar studies for the moringa leaf, such as the one that determined $4.58 \%$ polyunsaturated fatty acids, $0.87 \%$ monounsaturated fatty acids and $3.77 \%$ saturated fatty acids [43]. The values are lower than those of corn oil, which contains $14 \%$ saturated fatty acids, 30\% monounsaturated fatty acids and 56\% polyunsaturated fatty acids, 54-60\% linoleic acid, $25-31 \%$ oleic acid, $11-13 \%$ palmitic acid, 2-3\% linolenic acid [44]. This last reference of linolenic acid, with $2-3 \%$ in concentration, is slightly higher than the one evaluated here in moringa leaves, of $1.54 \%$. Other reports express much higher concentrations of linolenic acid than those found here, such as that reported in moringa leaves from South Africa of $44.57 \%$, who mention the presence of 17 fatty acids [37]. These variations could be attributed to different climatic conditions and soil types. This results with almost twice as many polyunsaturated $(1.54 \%)$ than saturated $(0.72 \%)$ fatty acids, which is favorable in the diet. Polyunsaturated fatty acids support the functionality of the immune system. On the contrary, saturated fats are associated with cardiovascular diseases [45]. In relation to the profile of long chain fatty acids, moringa leaf has a higher abundance of linolenic acid (C18:3) and palmitic acid (C16:0) than stearic acid (C18:0) and oleic (C18:1). linolenic acid (omega 3) is an essential polyunsaturated fatty acid (organisms cannot produce it), so it must be acquired through the diet. It is a fundamental compound for the functioning of cell membranes, especially neuronal ones. It is associated with a lower risk of developing diseases such as dementia or Alzheimer's, reduces cholesterol levels, has antithrombotic and vasodilatory, anti-inflammatory properties, prevents diabetes and certain types of cancer [46]. On the other hand, palmitic acid is associated with an increase in blood cholesterol, stearic acid does not affect it, and oleic acid is related to a decrease in blood cholesterol [47].

Due to these favorable characteristics, moringa has become one of the most widely used species as a dietary supplement for forage, either directly or ensiled, with favorable effects on milk yield in cows [48], higher intake and digestibility [49], higher content of milk fat [50].

\section{Conclusion}

The consumption of moringa (leaves and other anatomical parts) in its various forms has beneficial effects on nutrition and health, in the treatment and prevention of various diseases due to the biochemical compounds that this plant contains. It has a high yield in biomass, and it has been used in animal nutrition, since the quality of the various animal products for human consumption is improved. It can be a source of chemical products destined for health, due to the polyphenolic concentration, vitamins and polyunsaturated fatty acids of the omega type. 


\section{Conflict of Interest}

There is not any conflict of interest.

\section{Bibliography}

1. Movahhedkhah S., et al. "Summer savory (Satureja hortensis L.) extract as natural feed additive in broilers: Effects on growth, plasma constituents, immune response, and ileal microflora". Animals 9.87 (2019): 1-8.

2. Peraza González B., et al. "Efecto de la alimentación con Moringa oleífera en la dieta de vacas lecheras". Revista Ingeniería Agrícola 5.4 (2015): 40-45.

3. Olson ME and Fahey JW. "Moringa oleifera: un árbol multiusos para las zonas tropicales secas". Revista Mexicana de Biodiversidad 82.4 (2011): 1071-1082.

4. Leone A., et al. "Cultivation, genetic, ethnopharmacology, phytochemistry and pharmacology of Moringa oleifera leaves: An overview". International Journal of Molecular Science 16 (2015): 12791-12835.

5. Onunkwo DN and George OS. "Effects of Moringa oleifera leaf meal on the growth performance and carcass characteristics of broiler birds". Journal of Agriculture and Veterinary Science 8 (2015): 63-66.

6. Saini RK., et al. "Effect of dehydration methods on retention of carotenoids, tocopherols, ascorbic acid and antioxidant activity in Moringa oleifera leaves and preparation of a RTE product". Journal of Food Science and Technology 51 (2014): 2176-2182.

7. Rodríguez-Pérez C., et al. “Optimization of extraction method to obtain a phenolic compounds-rich extract from Moringa oleifera Lam leaves". Industrial Crops and Products 66 (2015): 246-254.

8. Anwar F., et al. "Moringa oleífera: a food plant with multiple medicinal uses”. Phytotherapy Research 21 (2007): 17-25.

9. Alvarado-Ramírez ER., et al. "Moringa oleifera Lam.: una alternativa forrajera en la producción pecuaria en México". Agro Productividad 11 (2017): 106-110.

10. Olugbemi TS., et al. "Effect of Moringa (Moringa oleifera) inclusion in cassava-based diets fed to broiler chickens". International Journal of Poultry Science 9 (2010): 363-367.

11. Kholif AE., et al. "Moringa oleifera leaf meal as a protein source in lactating goat's diets: Feed intake, digestibility, ruminal fermentation, milk yield and composition, and its fatty acids profile". Small Ruminant Research 129 (2015): 129-137.
12. Gopalakrishnan L., et al. "Moringa oleifera: A review on nutritive importance and its medicinal application". Food Science and Human Wellness 5 (2016): 49-56.

13. Valdez-Solana MA., et al. "Nutritional Content and Elemental and Phytochemical Analyses of Moringa oleifera Grown in Mexico". Journal of Chemistry (2015): 1-9.

14. Van Soest PJ., et al. "Methods for Dietary Fiber, Neutral Detergent Fiber, and Nonstarch Polysaccharides" in Relation to Animal Nutrition". In: Symposium: Carbohydrate methodology, metabolism, and nutritional implications in dairy cattle. Journal of Dairy Science 74 (1991): 3583-3593.

15. Urribarrí C AL., et al. "Extracción y precipitación de las proteínas solubles del pasto elefante enano (Pennisetum purpureum Schum cv. Mott)". Revista de la Facultad de Agronomía 21.3 (2004): 268-279.

16. AOAC. "Official method of analysis". 18th edition. Association of Official Analytical Chemists, Gathersburg (2010).

17. NMX-F-490-1999-NORMEX. "Alimentos. Aceites y grasas". Determinación de la composición de ácidos grasos a partir de C6 por cromatografía de gases.

18. Singleton VL and Rossi J AJr. "Colorimetry of total phenolics with phosphomolybdic-phosphotungtic acid reagent". American journal of Enology and Viticulture 16 (1965): 144-158.

19. Zhishen J., et al. "The determination of flavonoid contents in mulberry and their scavenging effects on superoxide radicals". Food Chemistry 64 (1999): 555-559.

20. Deshpande SS and Chetyan M. "Evaluation of vainillin assay for tannin analysis of dry beans". Journal of Food Science 50 (1985): 905-916.

21. Li Z., et al. "Oligosaccharides are a key factor in prediction of amino acid digestibility in soybean meal of different origins when fed to growing pigs". Asian-Australasian Journal of Animal Science 30.12 (2017): 1724-1732.

22. Robet E., et al. "Comparative Study of Nutritional Value of Wheat, Maize, Sorghum, Millet, and Fonio: Some Cereals Commonly Consumed in Côte d'Ivoire". European Scientific Journal edition 16.21 (2020): 118-131.

23. Nweze NO and Nwafor F. "Phytochemical, Proximate and Mineral Composition of Leaf Extracts of Moringa oleifera Lam. from Nsukka, South-Eastern Nigeria". OSR Journal of Pharmacy and Biological Sciences (IOSR-JPBS) 9.1 (2014): 99-103. 
24. Aye P and Adegun MK. "Chemical composition and some functional properties of Moringa, Leucaena and Gliricidia leaf meals". Agriculture and Biology Journal of North America's 4 (2013): 71-77.

25. Bonekamp RPRT., et al. "Effects of amino acids on egg number and egg mass of brown (heavy breed) and white (light breed) laying hens". Poultry Science 89.3 (2010): 522-529.

26. Su B and Chen X. "Current Status and Potential of Moringa oleifera Leaf as an Alternative Protein Source for Animal Feed". Frontiers in Veterinary Science 7 (2020): 1-13.

27. Yang R., et al. "Nutritional and functional properties of Moringa leaves-from Germplasm, to plant, to food, to health". Moringa and other highly nutritious plant resources: Strategies, standards, and markets for a better impact on nutrition in Africa 11 (2006): 16-18.

28. Jaiswal D., et al. "Role of Moringa oleifera in regulation of diabetes-induced oxidative stress". Asian Pacific Journal of Tropical Medicine10 (2013): 426-432.

29. Guzmán-Maldonado SH., et al. "Nutraceutical and nutritional quality of moringa leaf from trees of different height". Revista Mexicana de Ciencias Agrícolas 6.2 (2015): 317-330.

30. Qwele K., et al. "Chemical composition, fatty acid content and antioxidant potential of meat from goats supplemented with Moringa (Moringa Oleifera) leaves, sunflower cake and grass hay". Meat Science 93 (2013): 455-462.

31. Patra AK and Saxena J. "Exploitation of dietary tannins to improve rumen metabolism and ruminant nutrition". Journal of the Science of Food and Agriculture 164.3 (2011): 135-146.

32. Sreelatha S and Padma PR. "Antioxidant activity and total phenolic content of Moringa oleifera leaves in two stages of maturity". Plant Foods for Human Nutrition 64 (2009): 303-311.

33. Verma AR., et al. "In vitro and in vivo antioxidant properties of different fractions of Moringa oleifera leaves". Food and Chemical Toxicology 47 (2009): 2196-2201.

34. Lala AO., et al. "Effects of Moringa oleifera leaf meal on the quality, antioxidant and cholesterol content of eggs". Journal of agriculture and social sciences 10 (2012): 223-238.

35. Jansman AJM., et al. "Ileal and fecal digestibility in piglets of field beans (Vicia faba L.) varying in tannin content". Animal Feed Science and Technology 42 (1993): 83-96.
36. Ogbe AO and Affiku JP "Proximate study, mineral and antilnutrient composition of Moringa oleifera leaves harvested from Larfia, Nigeria: Potential benefits in poultry nutrition and health". Journal of Microbiology, Biotechnology and Food Sciences 1.3 (2012): 296-308.

37. Moyo B., et al. "Nutritional characterization of Moringa (Moringa oleifera Lam.) leaves". African Journal of Biotechnology 10.60 (2011): 12925-12933.

38. Abiose SH and Ikujenlola AV. "Comparison of chemical composition, functional properties and amino acids composition of quality protein maize and common maize (Zea may L)". African Journal of Food Science and Technology 5.3 (2014): 81-89.

39. Brosnan JT and Brosnan ME. "The sulfur-containing amino acids: an overview". Journal of Nutrition136 (2006): 1636S1640S.

40. Pi Z and Shen SH. "Research on paper mulberry as a new type of protein feedstuff”. Siliao Gongye 39 (2018): 23-8.

41. Farkhoy M., et al. "Evaluation of protein concentration and limiting amino acids including lysine and Met+ Cys in prestarter diet on performance of Broilers". Veterinary Medicine International 2012 (2012): 394189.

42. Feng L., et al. "Threonine Affects Intestinal Function, Protein Synthesis and Gene Expression of TOR in Jian Carp (Cyprinus carpio var. Jian)”. PLoS ONE 8.7 (2013): e69974.

43. Isitua CC., et al. "Phytochemical and nutritional properties of dried leaf powder of Moringa oleifera Lam. from machala el oro province of Ecuador". Asian Journal of Plant Science and Research 5.2 (2015): 8-16.

44. CRA. Corn oil (5th ed.). Washington, DC: Corn Refiners Association (2006).

45. Alfaia CPM., et al. "Effect of the feeding system on intramuscular fatty acids and conjugated linoleic acid isomers of beef cattle, with emphasis on their nutritional value and discriminatory ability" Food Chemistry 114 (2009): 939-946.

46. Rodríguez-Cruz M., et al. "Mecanismos moleculares de acción de los ácidos grasos poliinsaturados y sus beneficios en la salud". The Revista de Investigación Clínica 57.3 (2005): 457472.

47. Peña F., et al. "Effects of genotype and slaughter weight on the meat quality of Criollo Cordobes and Anglonubian kids produced under extensive feeding conditions". Meat Science 83 (2009): 417-422. 
48. Reyes-Sánchez $\mathrm{N}$ and Ledin and Ledin I. "Biomass production and chemical composition of Moringa oleifera under different management regimes in Nicaragua". Agroforestry Systems 66 (2006): 231-242.

49. Mendieta-Araica B., et al. "Silage quality when Moringa oleifeira is ensiled in mixtures with Elephant grass, sugar cane and molasses". Grass and Forage Science 64 (2009): 364-373.

50. Cohen-Zinder M., et al. "Effect of feeding lactating cows with ensiled mixture of Moringa oleifera, wheat hay and molasses, on digestibility and efficiency of milk production". Animal Feed Science and Technology 211 (2016): 75-83.

Volume 3 Issue 12 December 2021

(C) All rights are reserved by Lucía Barrientos

Ramírez., et al. 